\title{
Metabotropic Glutamate Receptor Subtype 7 Ablation Causes Deficit in Fear Response and Conditioned Taste Aversion
}

\author{
Miwako Masugi, ${ }^{1}$ Mineto Yokoi, ${ }^{1}$ Ryuichi Shigemoto,, ${ }^{2}$ Keiko Muguruma,, ${ }^{3}$ Yasuyoshi Watanabe, ${ }^{3}$ \\ Gilles Sansig, ${ }^{4}$ Herman van der Putten, ${ }^{4}$ and Shigetada Nakanishi ${ }^{1}$ \\ Departments of ${ }^{1}$ Biological Sciences and ${ }^{2}$ Morphological Brain Science, Kyoto University Faculty of Medicine, Kyoto 606 - \\ 8501, Japan, ${ }^{3}$ Department of Neuroscience, Osaka Bioscience Institute, Suita, Osaka 565-0874, Japan, and ${ }^{4}$ Novartis \\ Pharma AG, Nervous System Department, CH-4002 Basel, Switzerland
}

\begin{abstract}
Metabotropic glutamate receptors (mGluRs) consist of eight different subtypes and exert their effects on second messengers and ion channels via G-proteins. The function of individual mGluR subtypes in the CNS, however, largely remains to be clarified. We examined the fear response of freezing after electric shock in wild-type and mGluR ${ }^{-1}$ knockout littermates. Wild-type mice displayed freezing immediately after and $1 \mathrm{~d}$ after footshock. In comparison, mGluR $7^{-1-}$ knockout mice showed significantly reduced levels in both immediate postshock and delayed freezing responses. However, the knockout mice exhibited no abnormalities in pain sensitivity and locomotor activity. To further examine amygdala-dependent behavior, we performed conditioned taste aversion (CTA) experiments. In wild-type mice, the administration of saccharin followed by intraperitoneal injection of the malaise-inducing agent $\mathrm{LiCl}$ resulted in an association between saccharin and $\mathrm{LiCl}$. This
\end{abstract}

association caused strong CTA toward saccharin. In contrast, mGluR7 ${ }^{-1-}$ knockout mice failed to associate between the taste and the negative reinforcer in CTA experiments. Again, the knockout mice showed no abnormalities in taste preference and in the sensitivity to $\mathrm{LiCl}$ toxicity. These results indicate that mGluR7 deficiency causes an impairment of two distinct amygdala-dependent behavioral paradigms. Immunohistochemical and immunoelectron-microscopic analyses showed that mGluR7 is highly expressed in amygdala and preferentially localized at the presynaptic axon terminals of glutamatergic neurons. Together, these findings strongly suggest that mGluR7 is involved in neural processes subserving amygdala-dependent averse responses.

Key words: metabotropic glutamate receptor subtype 7; knockout mice; presynaptic receptor; fear response; conditioned taste aversion; amygdala
Glutamate receptors mediate most excitatory synaptic transmission in the CNS and play important roles in synaptic plasticity, neuronal development, and neurodegeneration (Mayer and Westbrook, 1987; Nakanishi, 1992; Hollmann and Heinemann, 1994; Nakanishi and Masu, 1994). Metabotropic glutamate receptors (mGluRs) are coupled to intracellular signal transduction via G-proteins and exert their effects on second messengers and ion channels (Nakanishi, 1994; Pin and Duvoisin, 1995; Conn and Pin, 1997). Eight different mGluR subtypes (mGluR1-mGluR8) have thus far been cloned and are classified into three groups according to their sequence identity, agonist selectivities, and signal transduction mechanisms. mGluR7 is a member of group III mGluRs. This receptor is coupled to inhibition of cyclic AMP cascade as shown in heterologously mGluR7-expressing cells and selectively activated by L-2-amino-4-phosphonobutyrate (L-AP4) (Okamoto et al., 1994; Saugstad et al., 1994). Compared with other mGluRs, mGluR7 is the most highly conserved across different mammalian species (Makoff et al., 1996). mGluR7 is

Received Sept. 17, 1998; revised Nov. 20, 1998; accepted Nov. 20, 1998.

This work was supported in part by research grants from the Ministry of Education, Science and Culture of Japan, the Ministry of Health and Welfare of Japan, the Sankyo Foundation, the Yamanouchi Foundation, and the Biomolecular Engineering Research Institute. We thank Takashi Yamamoto for advice on CTA experiments, Fumitaka Ushikubi for advice on the nociception test, Markus Schroeder for back-crossing of mutant mice, Ayae Kinoshita for the kind gift of antibodies, Akira Uesugi for photography, and Kumlesh K. Dev for careful reading of this manuscript.

Correspondence should be addressed to Shigetada Nakanishi, Department of Biological Sciences, Kyoto University Faculty of Medicine, Yoshida, Sakyo-ku, Kyoto 606-8501, Japan.

Copyright (C) 1999 Society for Neuroscience $\quad 0270-6474 / 99 / 190955-09 \$ 05.00 / 0$ widely distributed throughout the CNS (Kinzie et al., 1995; Ohishi et al., 1995; Bradley et al., 1996; Kinoshita et al., 1998). It is localized presynaptically close to release sites and has a low affinity for L-glutamate (Okamoto et al., 1994; Saugstad et al., 1994; Shigemoto et al., 1996, 1997; Kinoshita et al., 1998). Furthermore, presynaptic inhibition of glutamate release by L-AP4 has been observed in many glutamatergic projection neurons (Forsythe and Clements, 1990; Baskys and Malenka, 1991; Rainnie and Shinnick-Gallagher, 1992). Although mGluR7 has been postulated to play an important role in synaptic modulation, a lack of pharmacological tools prevents a clear definition of such roles in brain function.

In this investigation, we used mGluR7-deficient mice generated by targeted disruption of the mGluR7 gene and attempted to examine possible functions of mGluR7 in the CNS. Here, we report that mGluR7-deficient mice show a marked reduction in fear-mediated freezing responses during electric footshocks. In addition, these mice show an impairment in the ability to associate between a taste stimulus and a malaise-evoking $\mathrm{LiCl}$ injection [conditioned taste aversion (CTA)]. Because the amygdala function is essential for these two distinct behavioral paradigms, our results together with several control experiments strongly suggest that mGluR7 is critical in amygdala function.

\section{MATERIALS AND METHODS}

Generation of knockout mice. The detailed procedures for generation of mGluR7-deficient mice are elsewhere (G. Sansig and H. van der Putten, unpublished observations). Briefly, genomic clones containing the first coding exon of the mGluR7 gene were isolated from the $129 / \mathrm{SvJ}$ strain. 
A

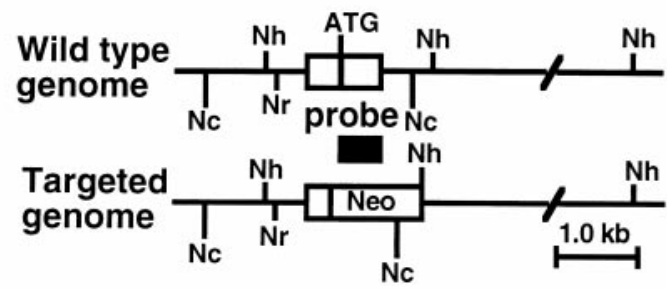

B Wild type
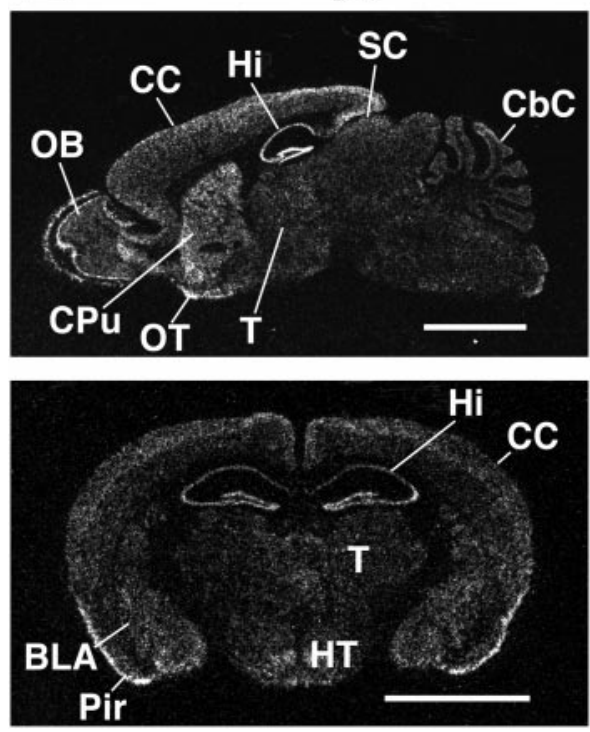

mGluR7 ${ }^{-/-}$
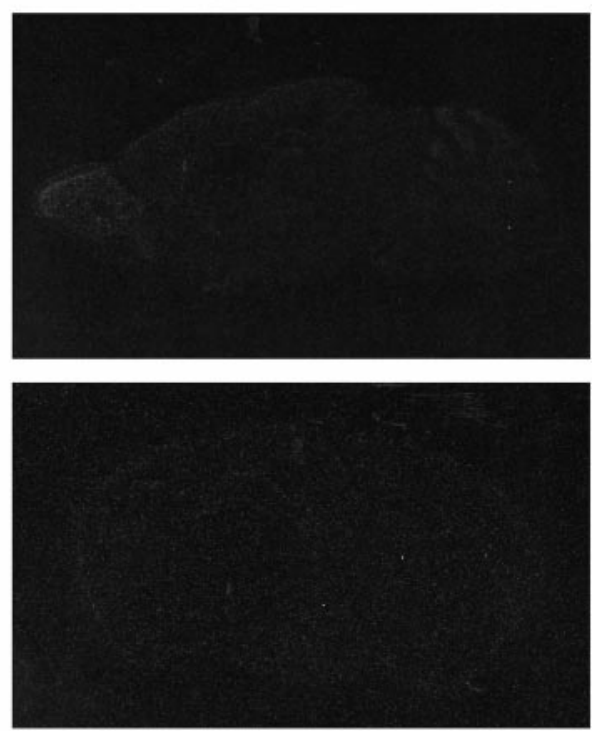

Figure 1. Targeted disruption of the mGluR7 gene. $A$, A scheme of the mGluR7 genomic DNA and its disrupted gene. The first coding exon is indicated by a box. Neo, Neomycin-resistance gene; $A T G$, translation initiation site. Restriction endonuclease cleavage sites: $N h, N h e \mathrm{I} ; \mathrm{Nr}, \mathrm{Nr} \mathrm{I}$; $\mathrm{Nc}, \mathrm{Nco}$ I. Location of the probe used for in situ hybridization analysis is indicated under the exon. $B$, Negative film images of in situ hybridization of sagittal (top) and coronal sections (bottom), showing the distribution of mGluR7 mRNA in brain sections of wild-type mice (left) and the lack of mGluR7 mRNA in sections of mGluR7 ${ }^{-1-}$ knockout mice (right). BLA, Basolateral amygdaloid nucleus; $C b C$, cerebellar cortex; $C C$, cerebral cortex; $C P u$, caudate putamen; $H i$, hippocampus; $H T$, hypothalamus; $O B$, olfactory bulb; OT, olfactory tubercle; Pir, piriform cortex; $S C$, superior colliculus; $T$, thalamus. Scale bar, $3 \mathrm{~mm}$. assessed by recording animal movements on video. Freezing involved the absence of all movements except for those related to respiration. Both stereotyped crouching posture and standing motionless were scored as freezing (Blanchard and Blanchard, 1969). After individual mice had been kept in stainless steel cages for at least 1 week, they were placed individually into a new chamber enclosed by a sound-attenuating cubicle (Coulbourn Instruments, Allentown, PA). After 3 min with no stimuli presented, the mice received either $10 \times 1 \mathrm{sec}$ or $3 \times 1 \mathrm{sec}$ electric footshocks $(0.7 \mathrm{~mA})$ with 1 min intershock intervals. Electric shock was generated by a grid floor shocker that was controlled by the HABITEST Universal Linc using L2T2 Operant Control Software (Coulbourn Instruments). The percentage of freezing response was determined before and immediately after each shock stimulus. This percentage was calculated by scoring the number of positive freezing responses divided by the total number of samples at $2 \mathrm{sec}$ intervals in a $1 \mathrm{~min}$ time period (i.e., 30 samples per minute). To determine any retention of the conditioned fear response, footshock-treated mice were returned to their home cages and kept for $24 \mathrm{hr}$. Immediately after the mice were returned to the footshock chamber, the percentage of freezing response was determined every 1 min with time sampling of every $6 \mathrm{sec}$ (i.e., 10 samples per minute).

Pain sensitivity. Naive mice were placed individually into the same chamber used for fear response and 3 min later were given a train of $1 \mathrm{sec}$ electric shocks at $10 \mathrm{sec}$ intervals with the following progression: 0.02 , $0.04,0.06,0.08,0.10,0.20,0.30,0.40,0.50$, and $0.60 \mathrm{~mA}$. The intensity of electric shocks that evoked vocalization (a cry separated from the initial awareness response), jump (jump, run, or prance), and flinch (a startle response different from the normal activity) was determined. Hot-plate test was performed as described by Eddy and Leimbach (1953). Mice were kept on the apparatus maintained at $25^{\circ} \mathrm{C}$ for $1 \mathrm{~min}$ and then placed on a metal surface maintained at $55^{\circ} \mathrm{C}$ (Ultra Hot Plate, Iuchi, Japan). The latency of jump and first avoidance (vigorous hindpaw shake, lick, or jump) was recorded for a maximum of $30 \mathrm{sec}$. Tail-flick test was performed as reported by D'Amour and Smith (1941). Mice were handled for a week until they became tame with handling. The mouse's tail was placed over a slit under which a photoelectric cell (Ugo Basile, Italy) was located. When heat was focused onto the tail, the mouse responded by

Fear responses. Freezing was used as an index of fear response and was 


\section{Wild type}
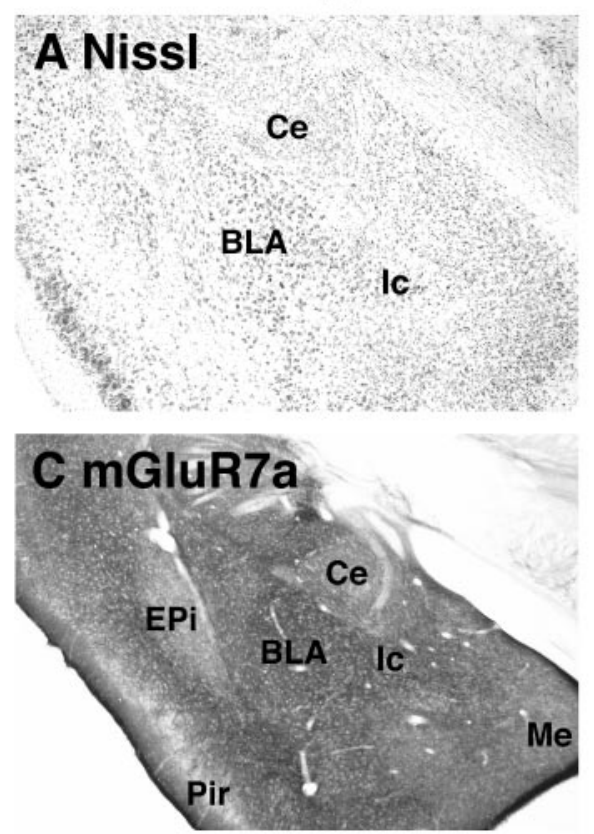

\section{E mGluR7b}

\section{$\mathrm{Ce}$}

BLA IC

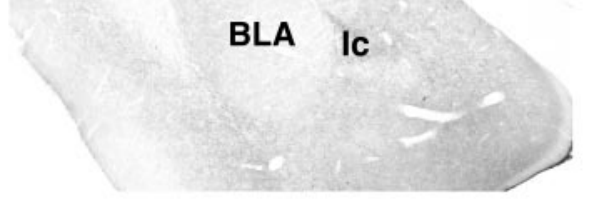

\section{G mGluR4a}

$\mathrm{Ce}$

BLA Ic

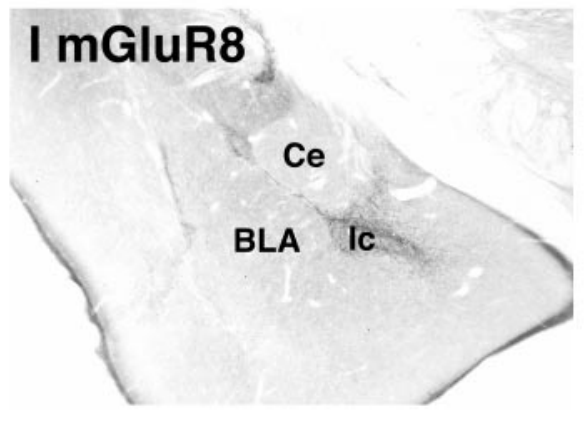

\section{mGluR7 ${ }^{-/-}$}

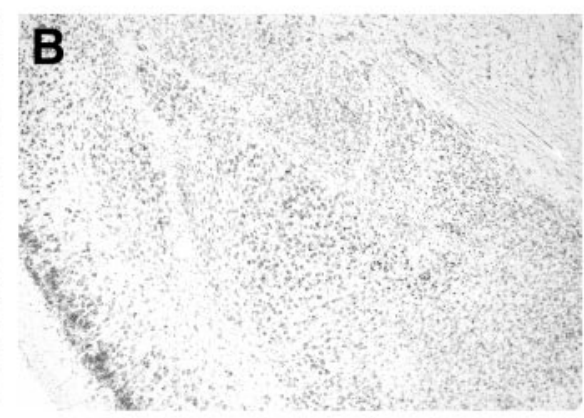

D

F
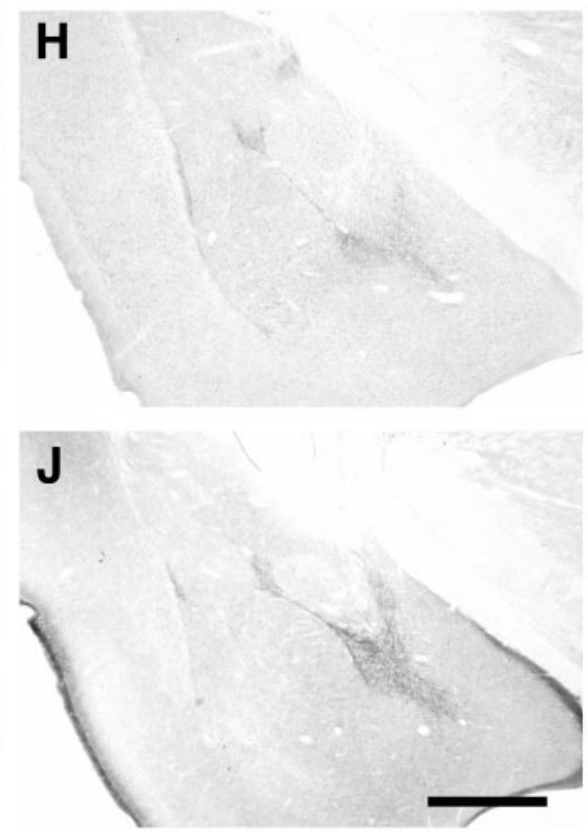

Figure 2. Histological and immunohistochemical analyses. Light microscope images of coronal sections are shown. No obvious change in the morphology of the amygdala was detected with Nissl staining of the $\operatorname{mGluR} 7^{-1-}$ knockout mouse as compared with the wild-type control $(A, B)$. Moderate to intense immunostaining of mGluR7a and weak immunostaining of mGluR7b were observed in the amygdala of wild-type mice, but these immunostainings totally disappeared in sections of mGluR7 $7^{-/-}$knockout mice $(C-F)$. No obvious change in the patterns and extents of mGluR4a and mGluR8 immunostainings was detected between wild-type and mGluR7 knockout mice $(G-J)$. BLA, Basolateral amygdaloid nucleus; $C e$, central amygdaloid nucleus; $E P i$, endpiriform nucleus; $I c$, intercalated nucleus; $M e$, medial amygdaloid nucleus; $P$ ir, piriform cortex. Scale bar, $500 \mu \mathrm{m}$. 

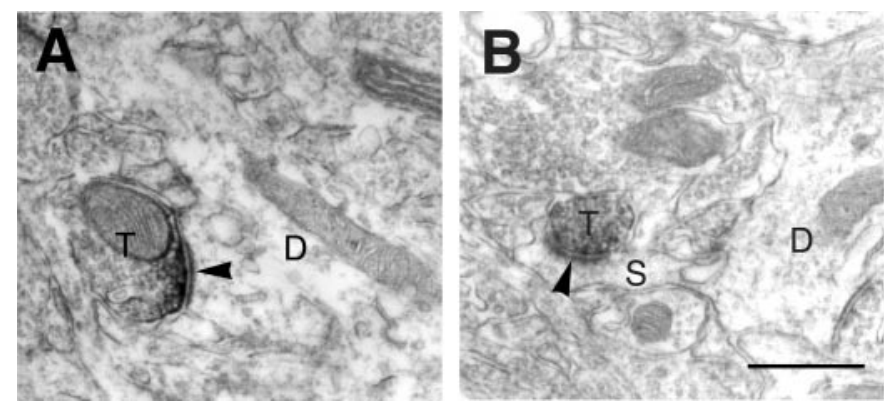

Figure 3. Immunoelectron-microscopic analysis. Electron micrographs showing immunoreactivity for mGluR7a in the BLA. Immunoreactive products for mGluR7a were accumulated along presynaptic membrane specialization in axon terminals $(T)$, making asymmetrical synapses (arrowheads) on dendrites $(D$ in $A)$ and spines $(S$ in $B)$. Scale bar, $0.5 \mu \mathrm{m}$.

flicking its tail out of the slit. As a result, light passed through the slit and activated a photocell that in turn stopped the recording timer automatically (a maximal recording of $20 \mathrm{sec}$ ); measurement of each mouse was repeated twice and averaged.

Open field. Spontaneous locomotor activity was assessed over a $30 \mathrm{~min}$ session with an infrared activity monitor (Coulbourn Instruments) in a chamber to which mice had not been previously exposed. The chamber was kept under a dim light and was sound-attenuated. The frequency of defecations (boluses) and urinations (spots) was recorded simultaneously.

Conditioned taste aversion. Mice were kept in polypropylene cages $(24 \times 17 \times 12 \mathrm{~cm})$. They were deprived of water for $20 \mathrm{hr}$ and trained to drink water from two bottles for $20 \mathrm{~min}$. Forty minutes later, the mice were supplied with water for $3 \mathrm{hr}$ and again deprived of water for $20 \mathrm{hr}$. This training was repeated five times (training days). On days 6 and 7 (conditioning days 1 and 2), the mice were presented with $0.005 \mathrm{M}$ saccharin sodium salt instead of water. Immediately thereafter they were injected with $0.15 \mathrm{M} \mathrm{LiCl}$ ( $2 \%$ of body weight) intraperitoneally as the malaise-inducing agent or with saline as control. Forty minutes later, they were presented with water for $3 \mathrm{hr}$ and then deprived of water for 20 hr. On day 8 (a rest day), the mice were presented with water in the same way as described in training days. CTA was tested on days 9 and 10. In this test, the mice were presented with two bottles, one containing saccharin and the other containing water, and their liquid consumption was recorded by weighing the two bottles before and after testing. The preference score was defined as saccharin/water + saccharin (milliliters consumed); the higher the preference score, the more the mice prefer saccharin to water. The average of total liquid consumption was $\sim 0.99$ $\mathrm{ml}$. Two out of 39 mice tested showed $<50 \%$ of this average of consumption and were omitted from the data analysis. The difference in sensitivity to various taste stimuli $(0.005 \mathrm{M}$ saccharin, $0.1 \mathrm{M} \mathrm{NaCl}$, and $0.01 \mathrm{M} \mathrm{HCl}$ ) was examined after $5 \mathrm{~d}$ training as described above.

\section{RESULTS}

\section{Histological analysis}

mGluR7 ${ }^{-1-}$ knockout mice were generated by replacing the first coding exon of the mGluR7 gene with the neomycin-resistance gene (Fig. 1A). In situ hybridization, using the antisense probe corresponding to the first mGluR7 coding exon, indicated that mGluR7 mRNA is expressed in many brain regions of wild-type mice and that this expression is completely lost in homozygous mGluR7 ${ }^{-1-}$ knockout mice (Fig. $1 B$ ). No hybridization was observed in adjacent sections using the sense probe as control (data not shown). We performed histological and immunohistochemical analyses on brain sections of wild-type and mGluR7 $7^{-/-}$ knockout mice (Fig. 2). Particular attention was given to the amygdala on the basis of behavioral analyses described in the next section. No gross anatomical change in the amygdala of mGluR7 ${ }^{-1-}$ knockout mice was detected by Nissl staining (Fig. $2 A, B)$. The distribution pattern of the two mGluR7 splice variants, mGluR7a and mGluR7b, was examined by using antibodies against the $\mathrm{C}$-terminal sequences specific to the two variants of
mGluR7. In wild-type mice, moderate to intense mGluR7a immunoreactivity was diffusely distributed in the basolateral amygdaloid nucleus (BLA), central amygdaloid nucleus (Ce), and intercalated nucleus (Ic) (Fig. 2C). mGluR7b immunoreactivity was weak but was clearly observed in the Ic (Fig. 2E). In mGluR7 ${ }^{-1-}$ knockout mice, neither mGluR7a nor mGluR7b immunoreactivity was detected throughout the brain, including the amygdala (Fig. 2D,F). Together, these results indicate that expression of mGluR7 is ablated in these knockout mice.

We also examined patterns and extents of immunostaining of other group III mGluRs. Both mGluR4a and mGluR8 immunoreactivities were relatively weak in the amygdala. However, immunostaining was localized in the Ic and in the border region between BLA, Ce, and Ic (Fig. 2G,I). No alteration in the pattern and extent of immunoreactivities for both mGluR4a and mGluR8 was noted in mGluR7 ${ }^{-1-}$ knockout mice (Fig. $2 H, J$ ). Therefore, it appears that ablation of mGluR7 expression in knockout mice has no effect on expression of other group III mGluRs in the amygdala.

The subcellular localization of mGluR7a immunoreactivity in the BLA of wild-type mice was examined by immunoelectronmicroscopic analysis. Most intense immunoreactivity in the axon terminals was observed in asymmetrical synaptic contacts with dendritic profiles (Fig. 3A). Moderate immunoreactivity for mGluR7a was also observed in some terminals making asymmetrical synapses with spines (Fig. $3 B$ ) and in preterminal portion of small unmyelinated axons filled with vesicles (data not shown). This analysis showed that mGluR7a is specialized in the axon terminals of glutamatergic neurons.

\section{Fear responses}

Young mGluR7 $7^{-1-}$ knockout mice appeared normal in behavior until $\sim 12$ weeks of age. Mice over 12 weeks old developed epilepsy, particularly when they were placed into a new chamber (Sansig and van der Putten, unpublished observations). Therefore, all behavioral trials were conducted on 6- to 8-week-old animals.

Animals show a stereotyped immobile crouching posture and stand motionless after footshock. This freezing response is an indicator of activation of the fear system (Blanchard and Blanchard, 1969; Bouton and Bolles, 1980; Fanselow, 1980). Figure 4 shows the mean percentage of freezing exhibited by wild-type and mGluR7 ${ }^{-1-}$ knockout mice. Before footshock, neither wild-type nor knockout mice exhibited freezing behavior. During the three 1 min intervals after footshock, wild-type mice displayed immediate postshock freezing that increased by repeated presentations of footshocks (Fig. 4A). mGluR7 ${ }^{-1-}$ knockout mice froze after footshock, but this freezing was significantly reduced in these knockout mice (Fig. 4A). In the above experiments, gendermatched littermates derived from heterozygous $\mathrm{mGluR} 7^{+/-}$mice were used. However, the genetic background of individual animals was a different mixture of the 129 and C57BL/6 strains. Because different strains have been reported to exhibit differences in freezing response (Chen et al., 1996), we back-crossed the original mGluR7 ${ }^{-1-}$ knockout mice into the C57BL/6 genetic background for seven generations and examined fear response of littermates derived from these mice in more detail. When repetitive footshocks were applied to wild-type mice with 1 min intervals, they showed immediate postshock freezing (Fig. 4B). The frequency of this freezing response increased over the number of footshocks and reached a maximal level during seven to eight times of repeated footshock applications. mGluR $7^{-1-}$ knockout 

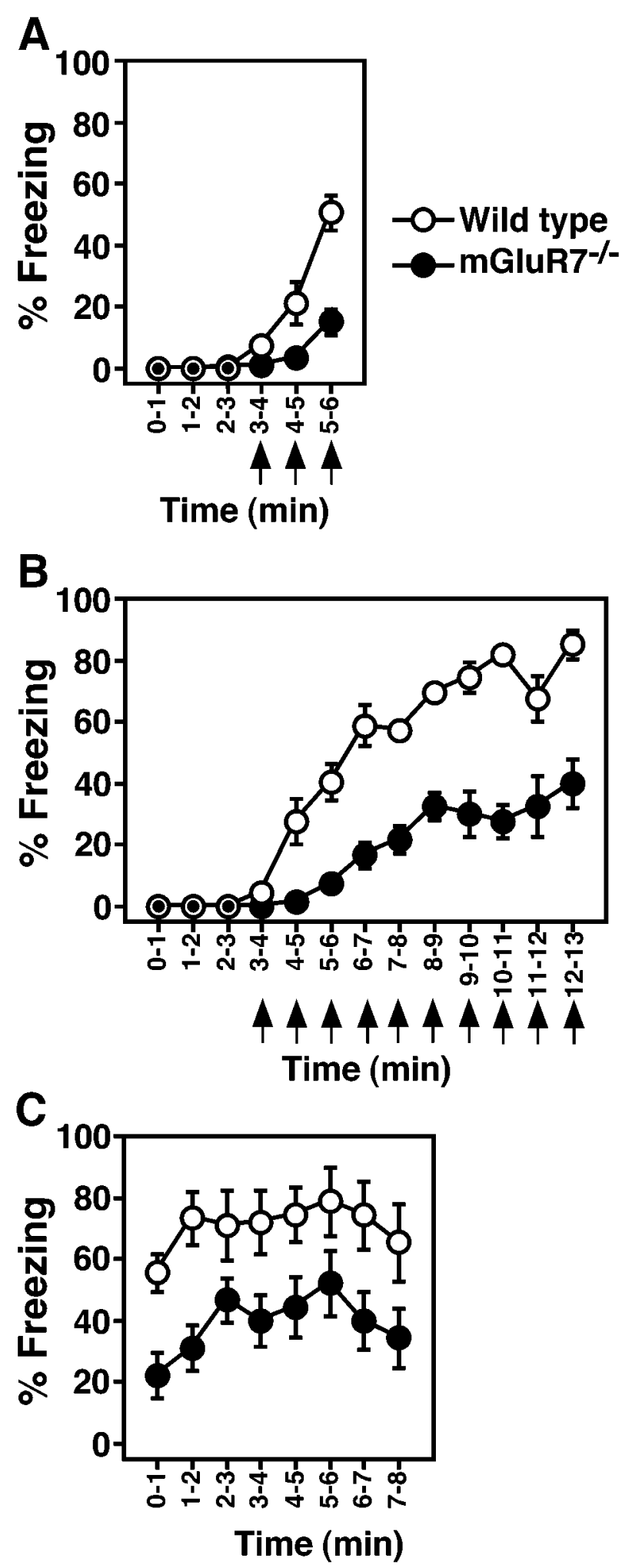

Figure 4. Freezing responses. $A$, Mean percentages of freezing immediately after footshocks. Percentage freezing was determined by timesampling at $2 \mathrm{sec}$ intervals. Three $\times 1 \mathrm{sec}$ footshocks $(0.7 \mathrm{~mA}$, arrows $)$ were given at 3,4 , and 5 min after animals had been placed in a new footshock-equipped chamber. Data points and bars represent mean \pm SEM, respectively $(n=11)$. ANOVA with repeated measures revealed a significant main effect of genotype $\left(F_{(1,20)}=18.5, p=0.0004\right)$ and a significant interaction between genotype and time $\left(F_{(5,100)}=14.2, p<\right.$ $0.0001) . B$, Mean percentages of freezing before and during 10 footshocks were determined as described in $A$. The $\operatorname{mGluR} 7^{-1-}$ knockout mice used mice clearly exhibited an immediate postshock freezing response. However, the frequency of this response was significantly less than that seen in wild-type mice throughout the points of repetitive footshocks. Furthermore, the freezing response in mGluR7 ${ }^{-1-}$ knockout mice reached a plateau phase at about a half of the maximal freezing response of wild-type mice (Fig. $4 B)$. We also examined the freezing response $24 \mathrm{hr}$ after footshock (Fig. 4C). When wild-type animals were returned to the shock chamber, they froze in the absence of footshock with similar maximal levels compared with the immediate postshock freezing. This observation indicates a retention of the fear response. The return of knockout mice into the footshock chamber also evoked freezing response, but the level of freezing in knockout mice was significantly lower than that of wild-type mice (Fig. $4 C$ ). However, this level was comparable to that of the immediate postshock freezing seen in these mice. These results indicate that mGluR7 ${ }^{-1-}$ knockout mice show an impairment of fearmediated freezing response but retain the ability to express the once memorized fear response.

Reduced pain could result in less freezing (Fanselow and Bolles, 1979). We tested whether the mGluR7 mutation may change nociceptive reactions to electric shock under the conditions used for the freezing studies. We measured the minimal currents required to elicit three stereotyped reactions against footshock: flinch, jump, and vocalization. Figure $5 A$ indicates that there was no significant difference in these nociceptive reactions between mGluR $7^{-1-}$ knockout and wild-type mice. We also examined pain sensitivity of the two genotypes with three additional behavioral analyses: tail-flick, hot-plate avoidance, and hot-plate jump. For all three analyses, mGluR7 ${ }^{-1-}$ knockout mice showed thresholds comparable to those of wild-type mice (Fig. 5B). It is therefore unlikely that the attenuated freezing response of $\mathrm{mGluR}^{-/-}$knockout mice is caused by reduced pain sensitivity.

Change in motor activity or autonomic alteration may also affect the frequency of fear response. Under open-field conditions, we compared locomotor activity and the frequency of defecation and urination of wild-type and $\mathrm{mGluR}^{-1-}$ mutant mice. This analysis indicated no significant difference in the locomotor activity or number of defecations and urinations between these two genotypes (Fig. 6A,B). These results strongly suggest that the reduced fear response of mGluR $7^{-1-}$ knockout mice is caused by a fear-specific abnormality rather than modifications in freezing-related sensory or motor processing capacities.

\section{Conditioned taste aversion}

Lesion and pharmacological analyses have indicated that the amygdala plays an essential role in establishment of fear response

in $B$ and $C$ were generated by back-crossing the original mGluR $7^{-1-}$ knockout mice into the C57BL/6 genetic background for seven generations. Data points and bars in $B$ and $C$ represent mean \pm SEM, respectively $(n=9)$. ANOVA with repeated measures revealed a significant main effect of genotype $\left(F_{(1,16)}=57.9, p<0.0001\right)$ and a significant interaction between genotype and time $\left(F_{(12,192)}=10.8, p<0.0001\right)$. $C$, The footshock-treated animals in $B$ were returned to their home cages for $24 \mathrm{hr}$. Immediately after the mice were returned to the footshock chamber, percentage freezing was determined by time-sampling at $6 \mathrm{sec}$ intervals. ANOVA with repeated measures revealed a significant main effect of genotype $\left(F_{(1,16)}=9.0, p=0.0085\right)$ and a nonsignificant interaction between genotype and time $\left(F_{(7,112)}=0.36, p=0.92\right)$. Overall, mGluR7 ${ }^{-/-}$knockout mice exhibited significantly less freezing than wild-type, immediately after and $24 \mathrm{hr}$ after footshock. 

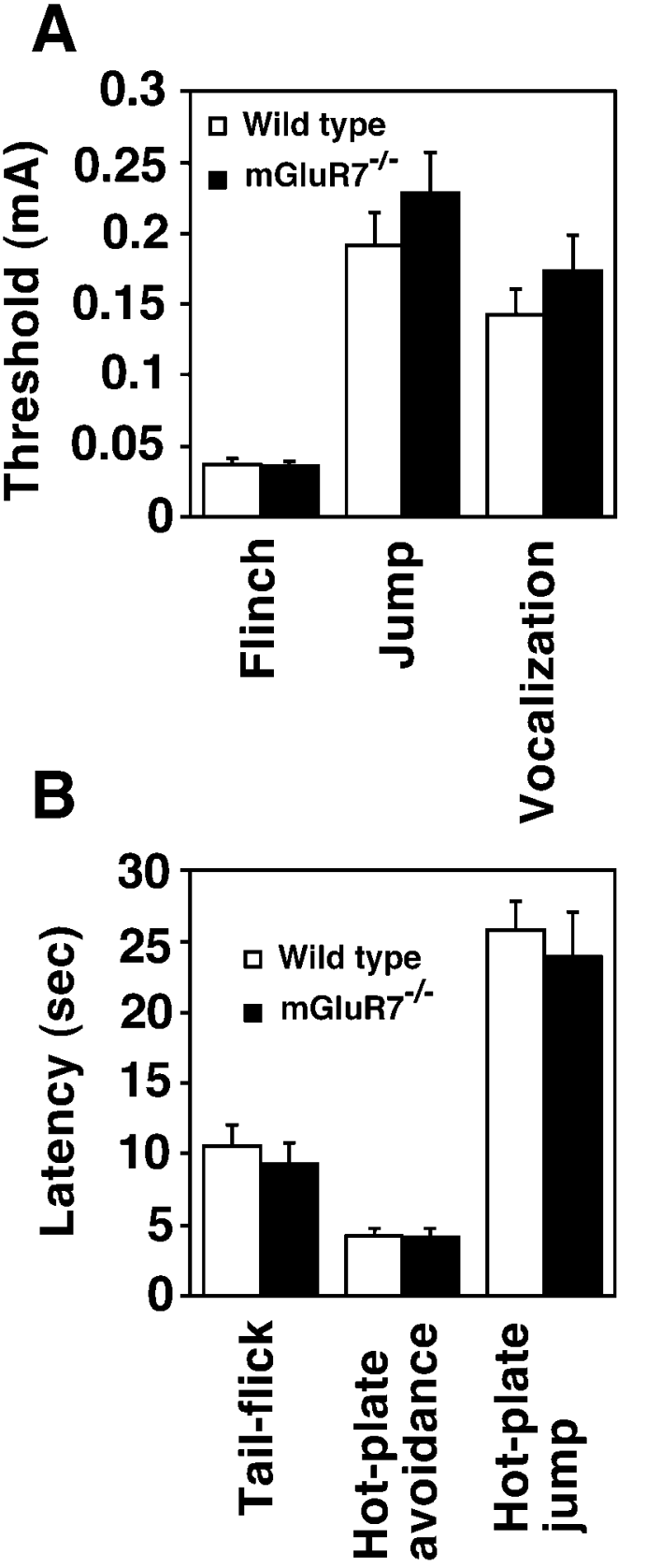

Figure 5. Pain sensitivity. A, The minimal amounts of currents required to elicit flinch, jump, and vocalization in responses to footshock were determined for wild-type and mGluR7 $7^{-1-}$ knockout mice $(n=16) . B$, The latencies for first avoidance and jump in the hot-plate test and for tail-flick were determined for the two genotypes $(n=6)$. Columns and bars represent mean \pm SEM, respectively. Statistical analyses using Student's $t$ test indicated no difference in any of the behavioral tests between the two genotypes: for flinch $\left(t_{(30)}=0.26, p=0.80\right)$, jump $\left(t_{(30)}=-1.0\right.$, $p=0.32)$, vocalization $\left(t_{(30)}=-0.99, p=0.33\right)$, tail-flick $\left(t_{(10)}=0.63, p=\right.$ $0.54)$, first avoidance $\left(t_{(10)}=0.11, p=0.92\right)$, and jump in the hot-plate test $\left(t_{(10)}=0.51, p=0.62\right)$.

to contextual cues such as an experimental chamber (Blanchard and Blanchard, 1972; Davis et al., 1994; Maren and Fanselow, 1996; Rogan and LeDoux, 1996), although lasting memory in fear response is dependent on both amygdala and hippocampal functions (Phillips and LeDoux, 1992). To study another amygdaladependent task in mGluR7-deficient mice, we performed CTA experiments (Yamamoto et al., 1994) (Fig. 7). In CTA studies,
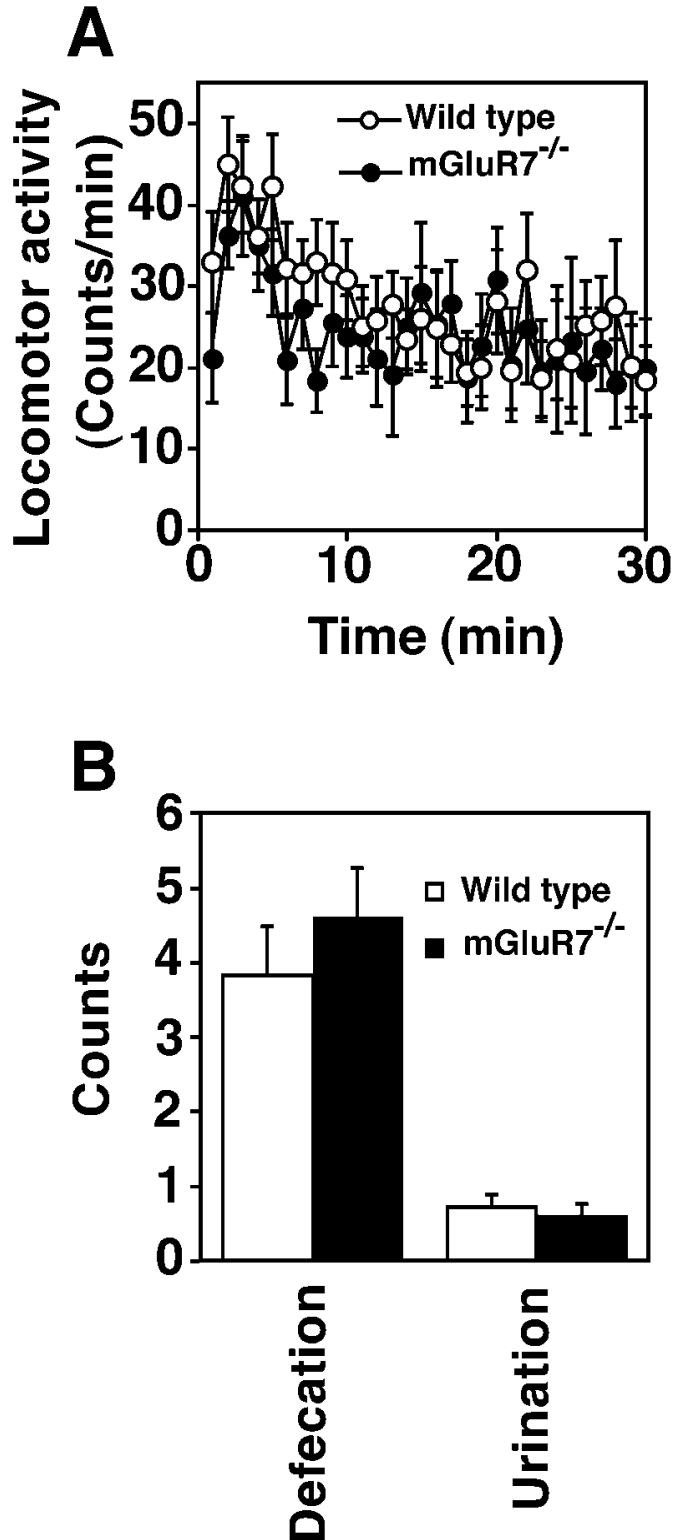

Figure 6. Open-field test. A, Spontaneous locomotor activity of wildtype and mGluR7 $7^{-1-}$ knockout mice $(n=9)$ was determined by the total amount of activity during each 1 min time period after the animals had been placed in a novel open-field environment. ANOVA with repeated measures indicated no reliable difference in genotype $\left(F_{(1,16)}=0.32, p=\right.$ $0.58)$ or interaction between genotype and time $\left(F_{(29,464)}=0.69, p=0.89\right)$ in locomotor activity. $B$, Mean numbers of defecations and urinations of the two genotypes $(n=18)$ were determined for the first $30 \mathrm{~min}$ after the animals had been placed in a novel open-field environment. Data points and bars represent mean \pm SEM, respectively. There was no statistical difference in any of the tests between two genotypes by Student's $t$ test: for defecations $\left(t_{(34)}=0.85, p=0.40\right)$ and urinations $\left(t_{(34)}=-0.52, p=\right.$ 0.61 ). In both $A$ and $B$, mGluR $7^{-1-}$ knockout and wild-type mice generated by back-crossing into the C57BL/6 genetic background for seven generations were used.

animals learn the taste stimuli that cause a toxic effect and remember to avoid repeated food intake. Strong CTA can be established in animals by administering saccharin followed by intraperitoneal injection of $\mathrm{LiCl}$, an agent that elicits transient visceral malaise.

Animals were presented with saccharin and then subjected to an intraperitoneal injection of either $\mathrm{LiCl}$ or saline. This taste 


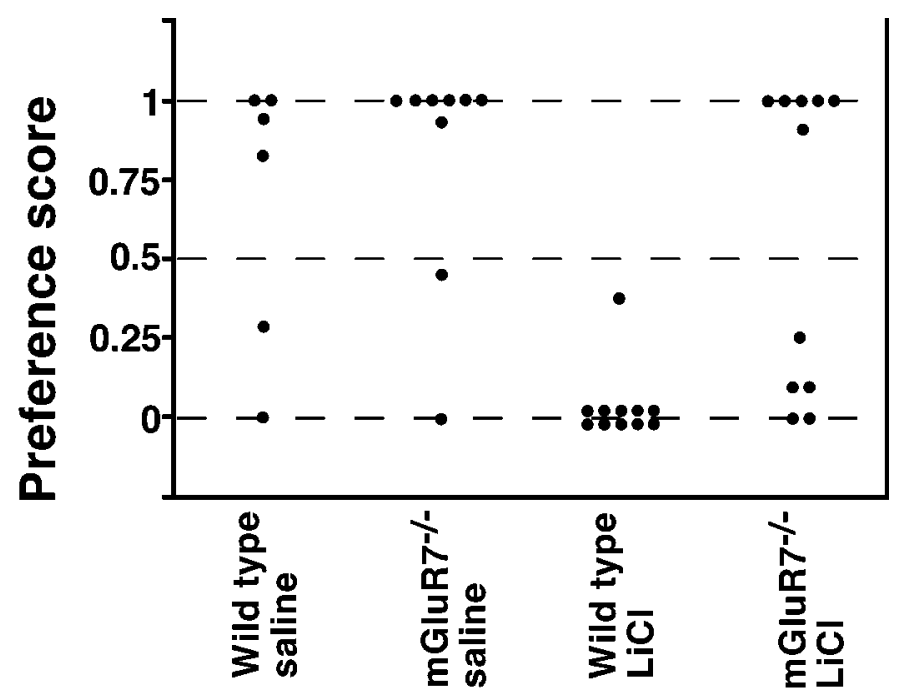

Figure 7. Performance of CTA. The data are expressed as relative ratios in the amount of drinking saccharin (milliliters)/water and saccharin (milliliters), using the two-bottle choice procedure as described in Materials and Methods. Each data point represents the result determined for one mouse. There was no difference in the preference of drinking saccharin between wild-type and mGluR $7^{-1-}$ knockout mice when saline was injected into these mice (wild-type vs $\mathrm{mGluR}^{-1-}: U=18.5, p=$ 0.28). $\mathrm{LiCl}$ injection into wild-type mice resulted in a marked aversion to saccharin (wild-type, saline vs wild-type, LiCl: $U=7, p=0.0022$ ). In mGluR7 ${ }^{-1-}$ knockout mice, CTA memory was markedly reduced (wildtype, $\mathrm{LiCl}$ vs mGluR7 ${ }^{-1-}$, $\left.\mathrm{LiCl}: U=15, p=0.001\right)$. Statistical analysis was performed using the Mann-Whitney test.

aversion conditioning or control saline injection was repeated twice. In test procedures, the animals were presented with two bottles, one containing saccharin and the other containing water, and their liquid consumption was recorded by weighing the two bottles before and after testing. In control experiments with injection of saline, both wild-type and mGluR7 ${ }^{-1-}$ knockout mice preferred saccharin to water. In wild-type mice, CTA was observed toward saccharin, indicating that these mice were able to develop an association between saccharin taste and the toxic effect of $\mathrm{LiCl}$. In contrast, mGluR7 ${ }^{-/-}$knockout mice were unable to associate saccharin with a malaise-evoking $\mathrm{LiCl}$ injection and drank either saccharin or water, depending on individual mice. This observation, however, raised the possibility that some but not all knockout mice retained the ability to learn the task of taste aversion. However, we also noticed that individual mice continued to drink from the first bottle from which they had begun to drink. We thus ran a follow-up survey on the taste preference of individual mice $24 \mathrm{hr}$ after the first test (data not shown). Nine of 11 wild-type mice again drank only water. In contrast, mGluR $7^{-1-}$ knockout mice drank either saccharin or water on test day 2. Furthermore, this segregation occurred randomly in individual mice, when the taste preference of individual mice was compared between test day 1 and test day 2 . These observations indicate that mGluR $7^{-1-}$ knockout mice are indeed defective in associating the taste stimulus with the negative reinforcer.

Normally, mice prefer saccharin and $\mathrm{NaCl}$ to water, whereas they do not like $\mathrm{HCl}$ (Flynn et al., 1991; Yamamoto et al., 1995). Both mGluR7 ${ }^{-1-}$ knockout mice and wild-type mice exhibited these normal taste preferences, with no differences occurring between the two genotypes (Fig. 8). We also monitored the sensitivity of the mice to $\mathrm{LiCl}$ toxicity by measuring the time it

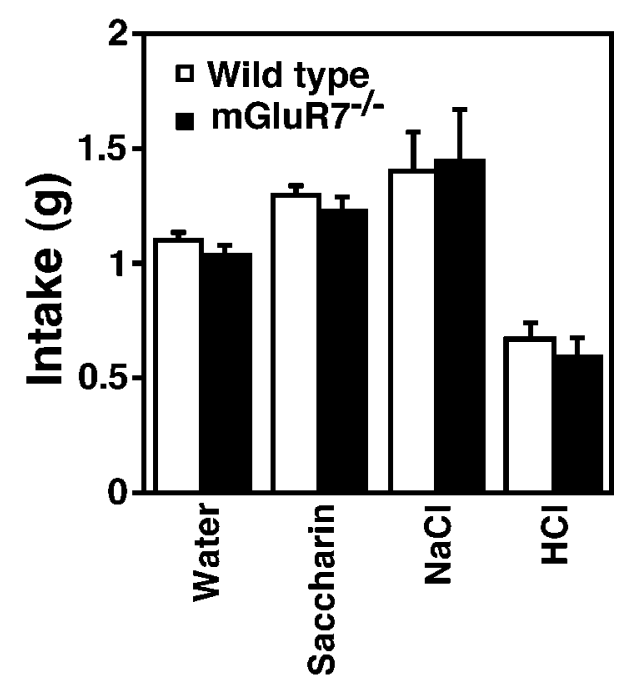

Figure 8. Taste preference. The preference for different taste solutions was examined. Columns and bars represent mean \pm SEM, respectively. Statistical analysis by Student's $t$ test indicated no significant change in taste preference between wild-type (wt) and knockout (ko) mice: for water $\left(n_{\mathrm{wt}}=61\right.$ and $\left.n_{\mathrm{ko}}=55 ; t_{(114)}=1.0, p=0.30\right)$, saccharin $\left(n_{\mathrm{wt}}=61\right.$ and $\left.n_{\mathrm{ko}}=55 ; t_{(114)}=0.91, p=0.36\right), \mathrm{NaCl}\left(n_{\mathrm{wt}}=18\right.$ and $n_{\mathrm{ko}}=11 ; t_{(27)}$ $=-0.14, p=0.89)$, and $\mathrm{HCl}\left(n_{\mathrm{wt}}=18\right.$ and $n_{\mathrm{ko}}=11 ; t_{(27)}=0.73, p=$ $0.47)$. Statistical analysis with Student's $t$ test revealed that compared with water, both wild-type and mGluR $7^{-1-}$ knockout mice drank more saccharin (wt: $t_{(120)}=-3.5, p=0.0007$; ko: $\left.t_{(108)}=-2.6, p=0.012\right)$ and $\mathrm{NaCl}$ (wt: $t_{(77)}=-2.7, p=0.0086$; ko: $\left.t_{(64)}=-2.8, p=0.006\right)$ and less $\mathrm{HCl}\left(\mathrm{wt}: t_{(77)}=5.4, p<0.0001\right.$; ko: $\left.t_{(64)}=3.9, p=0.0002\right)$.

took from the $\mathrm{LiCl}$ injection to the first occurrence of a "lying on the belly" posture (Meachum and Bernstein, 1990). Results indicated no difference in the toxic effect of $\mathrm{LiCl}$ injection between the two genotypes (data not shown). The mGluR $7^{-1-}$ knockout mice therefore showed no abnormalities in taste preference and in sensitivity to $\mathrm{LiCl}$ toxicity.

\section{DISCUSSION}

The present behavioral analysis of mGluR7 $7^{-/-}$knockout mice indicates that mGluR7 deficiency results in a marked reduction of freezing response to electric footshock and an impairment of CTA. In these knockout mice, a freezing deficit was observed both immediately (immediate postshock freezing) and $1 \mathrm{~d}$ (delayed freezing) after the shock presentation. Considerable evidence indicates that both types of freezing are conditional responses resulting from an association between the contextual cues of the chamber and the footshock (Blanchard et al., 1976; Bolles and Collier, 1976; Fanselow, 1986). Several control experiments have indicated that mGluR7 deficiency caused neither sensory nor motor performance deficits. In CTA experiments, the knockout mice failed to learn to avoid the taste stimulus that was paired with transient malaise. These mice were normal in taste preference and the sensitivity to $\mathrm{LiCl}$ toxicity. Thus, mGluR7 ablation impairs the ability to associate unconditional averse stimuli and conditional stimuli in both fear and CTA responses.

Various brain areas have been implicated in the process of conditioned fear response and CTA behavior. The amygdala constitutes a major element of the fear-conditioning circuitry (Davis et al., 1994; Maren and Fanselow, 1996; Rogan and LeDoux, 1996). Amygdala lesion blocks both immediate postshock and delayed freezing responses (Kim et al., 1993). Our results show a functional deficit of both immediate postshock and de- 
layed freezing responses in $\operatorname{mGluR} 7^{-1-}$ knockout mice that is consistent with amygdala dysfunction. The hippocampus is also crucial in dealing with fear response of a highly complex stimulus such as environmental context (Selden et al., 1991; Kim and Fanselow, 1992; Phillips and LeDoux, 1992; Kim et al., 1993). However, neurotoxic NMDA-mediated lesion of the dorsal hippocampus (DH) has been shown to disrupt delayed freezing but preserve immediate postshock freezing (Maren et al., 1997). In contrast, recent reports of electrolytic DH lesion analysis have indicated that the $\mathrm{DH}$ is involved in both the acquisition and expression of conditioned fear responses (Maren and Fanselow, 1997; Maren et al., 1997). Because mGluR7 is widely expressed in various brain regions including the hippocampus, it is possible that impaired fear responses in mGluR7 deficiency may result from functional deficits of the hippocampus. In addition, the periaqueductal gray is thought to be important in both the acquisition and expression of fear response (De Oca et al., 1998). Nonetheless, lesion of the periaqueductal gray has been shown to leave CTA memory unchanged (De Oca et al., 1998). In CTA behavior, it is generally accepted that the gustatory cortex, the parabrachial nucleus, and the amygdala play a pivotal role in the process of aversion learning (Yamamoto et al., 1994). Particularly, the indispensable role of the amygdala in CTA learning has been shown repeatedly by a number of different approaches (Rolls and Rolls, 1973; Nachman and Ashe, 1974; Simbayi et al., 1986). The present study has demonstrated that mGluR7 deficiency results in severe impairments of both conditioned fear responses and CTA. Therefore, these findings strongly suggest that mGluR7 is involved in neural processes that subserve amygdala-dependent aversion learning.

Various neurotransmitters and neuropeptides are involved in neural mechanisms of amygdala function. The involvement of NMDA and $\mathrm{GABA}_{\mathrm{A}}$ receptors in conditioned fear response has been reported by intra-BLA infusion of NMDA receptor antagonists and the $\mathrm{GABA}_{\mathrm{A}}$ receptor agonist muscimol (Miserendino et al., 1990; Fanselow and Kim, 1994; Helmstetter and Bellgowan, 1994; Maren et al., 1996; Muller et al., 1997). Furthermore, as in other brain systems, NMDA receptor function has been shown to be of mechanistic importance in the plasticity underlying amygdala-dependent fear conditioning (Maren, 1996; Rogan and LeDoux, 1996). We attempted to explore possible changes in functional NMDA receptors and/or $\mathrm{GABA}_{\mathrm{A}}$ receptors in mGluR $7^{-1-}$ knockout mice. In vitro quantitative autoradiography was examined in serial brain sections using the labeled NMDA receptor antagonist $\left[{ }^{3} \mathrm{H}\right] \mathrm{MK}-801$ and the benzodiazepine receptor antagonist $\left[{ }^{3} \mathrm{H}\right]$ Ro $15-1788$. For both ligands, no significant differences were observed in the amygdala of the two genotypes (data not shown). We further extended in vitro autoradiography to other ligands that have been implicated in fear response (Graeff, 1994; Hamon, 1994). These included serotonin 1A receptor agonist $\left[{ }^{3} \mathrm{H}\right] 8$-hydroxy-2-(di- $N$-dipropylamino)tetralin, serotonin 2 receptor antagonist $\left[{ }^{3} \mathrm{H}\right]$ ketanserin, dopamine D1 receptor antagonist $\left[{ }^{3} \mathrm{H}\right] \mathrm{SCH}-23390$, dopamine D2 receptor antagonist $\left[{ }^{3} \mathrm{H}\right] N$-methylspiperone, $\beta$-adrenergic receptor antagonist $\left[{ }^{3} \mathrm{H}\right]$ dihydroalprenolol, a partial inverse agonist of benzodiazepine receptor $\left[{ }^{3} \mathrm{H}\right]$ Ro $15-4513$, and glutamate receptor agonist $\left[{ }^{3} \mathrm{H}\right]$ kainate. None of these ligands showed any significant difference in their bindings at the amygdala between wild-type and mGluR7 ${ }^{-1-}$ knockout mice (data not shown).

Amygdala converges information from the cortex and various subcortical structures via glutamatergic projections, and it also sends outputs to several brain regions. Electrophysiological anal- ysis indicated that application of L-AP4 to amygdala slices reduces amplitudes of EPSPs but not the response to exogenous application of AMPA (Rainnie and Shinnick-Gallagher, 1992). Although this L-AP4-responsive receptor subtype remains to be identified, it is likely that the L-AP4-evoked reduction of EPSPs is mediated by mGluR7, which is most highly expressed in the amygdala among group III mGluR subtypes. Our immunoelectronmicroscopic analysis further indicated that mGluR7 immunoreactivity is preferentially localized in the presynaptic site of asymmetrical glutamatergic synapses of amygdala neurons. Thus, it is most likely that mGluR7 serves as a presynaptic autoreceptor in glutamatergic synapses and modulates excitatory synaptic transmission in the amygdala. Furthermore, in the CA1 region of hippocampal slices, Bushell et al. (1996) found a reduction in high-frequency synaptic transmission, post-tetanic potentiation, and short-term potentiation in $\mathrm{mGluR} 7^{-1-}$ knockout mice. These results were taken to suggest that mGluR7 is involved in short-term synaptic plasticity in the hippocampal CA1 region. Learning is believed to be embodied in persistent change in the transmission properties of neurons. Although the mechanism underlying the functional deficit in $\mathrm{mGluR} 7^{-1-}$ knockout mice awaits further investigation, the conspicuous behavioral abnormality of these mice will provide a useful system for investigating the mechanism underlying averse responses.

\section{REFERENCES}

Baskys A, Malenka RC (1991) Agonists at metabotropic glutamate receptors presynaptically inhibit EPSCs in neonatal rat hippocampus. J Physiol (Lond) 444:687-701.

Blanchard DC, Blanchard RJ (1972) Innate and conditioned reactions to threat in rats with amygdaloid lesions. J Comp Physiol Psychol 81:281-290.

Blanchard RJ, Blanchard DC (1969) Crouching as an index of fear. J Comp Physiol Psychol 67:370-375.

Blanchard RJ, Fukunaga KK, Blanchard DC (1976) Environmental control of defensive reactions to footshock. Bull Psychon Soc 8:129-130.

Bolles RC, Collier AC (1976) The effect of predictive cues on freezing in rats. Anim Learn Behav 4:6-8.

Bouton ME, Bolles RC (1980) Conditioned fear assessed by freezing and by the suppression of three different baselines. Anim Learn Behav 8:429-434.

Bradley SR, Levey AI, Hersch SM, Conn PJ (1996) Immunocytochemical localization of group III metabotropic glutamate receptors in the hippocampus with subtype-specific antibodies. J Neurosci 16:2044-2056.

Bushell TJ, Sansig G, Shigemoto R, Flor P, Kuhn R, Knoepfel T, Scheroeder M, Collett VL, Collingridge GL, van der Putten H (1996) An impairment of hippocampal synaptic plasticity in mice lacking mGlu7 receptors. Neuropharmacology 35:A6.

Chen C, Kim JJ, Thompson RF, Tonegawa S (1996) Hippocampal lesions impair contextual fear conditioning in two strains of mice. Behav Neurosci 110:1177-1180.

Conn PJ, Pin J-P (1997) Pharmacology and functions of metabotropic glutamate receptors. Annu Rev Pharmacol Toxicol 37:205-237.

D'Amour FE, Smith DL (1941) A method for determining loss of pain sensation. J Pharmacol Exp Ther 72:74-79.

Davis M, Rainnie D, Cassell M (1994) Neurotransmission in the rat amygdala related to fear and anxiety. Trends Neurosci 17:208-214.

De Oca BM, DeCola JP, Maren S, Fanselow MS (1998) Distinct regions of the periaqueductal gray are involved in the acquisition and expression of defensive responses. J Neurosci 18:3426-3432.

Eddy NB, Leimbach D (1953) Synthetic analgesics. II. Dithienylbutenyland dithienylbutylamines. J Pharmacol Exp Ther 107:385-393.

Fanselow MS (1980) Conditional and unconditional components of postshock freezing. Pavlov J Biol Sci 15:177-182.

Fanselow MS (1986) Associative vs topographical accounts of the immediate shock-freezing deficit in rats: implications for the response selection rules governing species-specific defensive reactions. Learn Motiv 17:16-39.

Fanselow MS, Bolles RC (1979) Naloxone and shock-elicited freezing in the rat. J Comp Physiol Psychol 93:736-744. 
Fanselow MS, Kim JJ (1994) Acquisition of contextual Pavlovian fear conditioning is blocked by application of an NMDA receptor antagonist D,L-2-amino-5-phosphonovaleric acid to the basolateral amygdala. Behav Neurosci 108:210-212.

Flynn FW, Grill HJ, Schwartz GJ, Norgren R (1991) Central gustatory lesions: I. Preference and taste reactivity tests. Behav Neurosci 105:933-943.

Forsythe ID, Clements JD (1990) Presynaptic glutamate receptors depress excitatory monosynaptic transmission between mouse hippocampal neurones. J Physiol (Lond) 429:1-16.

Graeff FG (1994) Neuroanatomy and neurotransmitter regulation of defensive behaviors and related emotions in mammals. Braz J Med Biol Res 27:811-829.

Hamon M (1994) Neuropharmacology of anxiety: perspectives and prospects. Trends Pharmacol Sci 15:36-39.

Helmstetter FJ, Bellgowan PS (1994) Effects of muscimol applied to the basolateral amygdala on acquisition and expression of contextual fear conditioning in rats. Behav Neurosci 108:1005-1009.

Hollmann M, Heinemann S (1994) Cloned glutamate receptors. Annu Rev Neurosci 17:31-108.

Kim JJ, Fanselow MS (1992) Modality-specific retrograde amnesia of fear. Science 256:675-677.

Kim JJ, Rison RA, Fanselow MS (1993) Effects of amygdala, hippocampus, and periaqueductal gray lesions on short- and long-term contextual fear. Behav Neurosci 107:1093-1098.

Kinoshita A, Ohishi H, Neki A, Nomura S, Shigemoto R, Takada M, Nakanishi S, Mizuno N (1996a) Presynaptic localization of a metabotropic glutamate receptor, mGluR8, in the rhinencephalic areas: a light and electron microscope study in the rat. Neurosci Lett 207:61-64.

Kinoshita A, Ohishi H, Nomura S, Shigemoto R, Nakanishi S, Mizuno N (1996b) Presynaptic localization of a metabotropic glutamate receptor, mGluR4a, in the cerebellar cortex: a light and electron microscope study in the rat. Neurosci Lett 207:199-202.

Kinoshita A, Shigemoto R, Ohishi H, van der Putten H, Mizuno N (1998) Immmunohistochemical localization of metabotropic glutamate receptors, mGluR7a and mGluR7b, in the central nervous system of the adult rat and mouse: a light and electron microscopic study. J Comp Neurol 393:332-352.

Kinzie JM, Saugstad JA, Westbrook GL, Segerson TP (1995) Distribution of metabotropic glutamate receptor 7 messenger RNA in the developing and adult rat brain. Neuroscience 69:167-176.

Makoff A, Pilling C, Harrington K, Emson P (1996) Human metabotropic glutamate receptor type 7: molecular cloning and mRNA distribution in the CNS. Brain Res Mol Brain Res 40:165-170.

Maren S (1996) Synaptic transmission and plasticity in the amygdala. An emerging physiology of fear conditioning circuits. Mol Neurobiol $13: 1-22$.

Maren S, Fanselow MS (1996) The amygdala and fear conditioning: has the nut been cracked? Neuron 16:237-240.

Maren S, Fanselow MS (1997) Electrolytic lesions of the fimbria/fornix, dorsal hippocampus, or entorhinal cortex produce anterograde deficits in contextual fear conditioning in rats. Neurobiol Learn Mem 67:142-9.

Maren S, Aharonov G, Stote DL, Fanselow MS (1996) $N$-methyl-Daspartate receptors in the basolateral amygdala are required for both acquisition and expression of conditional fear in rats. Behav Neurosci 110:1365-1374.

Maren S, Aharonov G, Fanselow MS (1997) Neurotoxic lesions of the dorsal hippocampus and Pavlovian fear conditioning in rats. Behav Brain Res 88:261-274.

Mayer ML, Westbrook GL (1987) The physiology of excitatory amino acids in the vertebrate central nervous system. Prog Neurobiol 28:197-276.
Meachum CL, Bernstein IL (1990) Conditioned responses to a taste conditioned stimulus paired with lithium chloride administration. Behav Neurosci 104:711-715.

Miserendino MJD, Sananes CB, Melia KR, Davis M (1990) Blocking of acquisition but not expression of conditioned fear-potentiated startle by NMDA antagonists in the amygdala. Nature 345:716-718.

Muller J, Corodimas KP, Fridel Z, LeDoux JE (1997) Functional inactivation of the lateral and basal nuclei of the amygdala by muscimol infusion prevents fear conditioning to an explicit conditioned stimulus and to contextual stimuli. Behav Neurosci 111:683-691.

Nachman M, Ashe JH (1974) Effects of basolateral amygdala lesions on neophobia, learned taste aversions, and sodium appetite in rats. J Comp Physiol Psychol 87:622-643.

Nakanishi S (1992) Molecular diversity of glutamate receptors and implications for brain function. Science 258:597-603.

Nakanishi S (1994) Metabotropic glutamate receptors: synaptic transmission, modulation, and plasticity. Neuron 13:1031-1037.

Nakanishi S, Masu M (1994) Molecular diversity and functions of glutamate receptors. Annu Rev Biophys Biomol Struct 23:319-348.

Ohishi H, Akazawa C, Shigemoto R, Nakanishi S, Mizuno N (1995) Distributions of the mRNAs for L-2-amino-4-phosphonobutyratesensitive metabotropic glutamate receptors, mGluR4 and mGluR7, in the rat brain. J Comp Neurol 360:555-570.

Okamoto N, Hori S, Akazawa C, Hayashi Y, Shigemoto R, Mizuno N, Nakanishi S (1994) Molecular characterization of a new metabotropic glutamate receptor mGluR7 coupled to inhibitory cyclic AMP signal transduction. J Biol Chem 269:1231-1236.

Phillips RG, LeDoux JE (1992) Differential contribution of amygdala and hippocampus to cued and contextual fear conditioning. Behav Neurosci 106:274-285.

Pin J-P, Duvoisin R (1995) The metabotropic glutamate receptors: structure and functions. Neuropharmacology 34:1-26.

Rainnie DG, Shinnick-Gallagher P (1992) Trans-ACPD and L-APB presynaptically inhibit excitatory glutamatergic transmission in the basolateral amygdala (BLA). Neurosci Lett 139:87-91.

Rogan MT, LeDoux JE (1996) Emotion: systems, cells, synaptic plasticity. Cell 85:469-475.

Rolls BJ, Rolls ET (1973) Effects of lesions in the basolateral amygdala on fluid intake in the rat. J Comp Physiol Psychol 83:240-247.

Saugstad JA, Kinzie JM, Mulvihill ER, Segerson TP, Westbrook GL (1994) Cloning and expression of a new member of the L-2-amino-4phosphonobutyric acid-sensitive class of metabotropic glutamate receptors. Mol Pharmacol 45:367-372.

Selden NRW, Everitt BJ, Jarrard LE, Robbins TW (1991) Complementary roles for the amygdala and hippocampus in aversive conditioning to explicit and contextual cues. Neuroscience 42:335-350.

Shigemoto R, Kulik A, Roberts JD, Ohishi H, Nusser Z, Kaneko T, Somogyi P (1996) Target-cell-specific concentration of a metabotropic glutamate receptor in the presynaptic active zone. Nature 381:523-525.

Shigemoto R, Kinoshita A, Wada E, Nomura S, Ohishi H, Takada M, Flor PJ, Neki A, Abe T, Nakanishi S, Mizuno N (1997) Differential presynaptic localization of metabotropic glutamate receptor subtypes in the rat hippocampus. J Neurosci 17:7503-7522.

Simbayi LC, Boakes RA, Burton MJ (1986) Effects of basolateral amygdala lesions on taste aversions produced by lactose and lithium chloride in the rat. Behav Neurosci 100:455-465.

Yamamoto T, Shimura T, Sako N, Yasoshima Y, Sakai N (1994) Neural substrates for conditioned taste aversion in the rat. Behav Brain Res 65:123-137.

Yamamoto T, Fujimoto Y, Shimura T, Sakai N (1995) Conditioned taste aversion in rats with excitotoxic brain lesions. Neurosci Res 22:31-49. 